\title{
A Deep-Big Data Approach to Health Care in the Al Age
}

\author{
José Neves ${ }^{1} \cdot$ Henrique Vicente ${ }^{1,2} \cdot$ Marisa Esteves $^{3} \cdot$ Filipa Ferraz $^{3} \cdot$ António Abelha $^{1} \cdot$ José Machado $^{1}$. \\ Joana Machado ${ }^{4}$. João Neves ${ }^{5} \cdot$ Jorge Ribeiro $^{6} \cdot$ Lúzia Sampaio $^{7}$
}

Published online: 27 June 2018

(C) Springer Science+Business Media, LLC, part of Springer Nature 2018

\begin{abstract}
The intersection of these two trends is what we call The Issue and it is helping businesses in every industry to become more efficient and productive. One's aim is to have an insight into the development and maintenance of comprehensive and integrated health information systems that enable sound policy and effective health system management in order to improve health and health care. Undeniably, different sorts of technologies have been developed, each with their own advantages and disadvantages, which will be sorted out by attending at the impact that Artificial Intelligence and Decision Support Systems have to everyone in the healthcare sector engaged to quality-of-care, i.e., making sure that doctors, nurses, and staff have the training and tools they need to do their jobs.
\end{abstract}

Keywords Artificial intelligence $\cdot$ Decision support systems $\cdot$ Medical imaging $\cdot$ Deep learning $\cdot$ Logic programming $\cdot$ Knowledge representation and reasoning $\cdot$ Artificial neural networks $\cdot$ Big data

José Neves

jneves@di.uminho.pt

Henrique Vicente

hvicente@uevora.pt

Marisa Esteves

marisa.araujo.esteves@gmail.com

Filipa Ferraz

filipatferraz@gmail.com

António Abelha

abelha@di.uminho.pt

José Machado

jmac@di.uminho.pt

Joana Machado

joana.mmachado@gmail.com

João Neves

joaocpneves@gmail.com
Jorge Ribeiro

jribeiro@estg.ipvc.pt

Lúzia Sampaio

luzia.sampaio@dbaj.ae

Centro Algoritmi, Universidade do Minho, Braga, Portugal

2 Departamento de Química, Escola de Ciências e Tecnologia, Centro de Química de Évora, Universidade de Évora, Évora, Portugal

3 Departamento de Informática, Universidade do Minho, Braga, Portugal

4 Farmácia de Lamaçães, Braga, Portugal

5 Mediclinic Arabian Ranches, PO Box 282602, Dubai, United Arab Emirates

6 Escola Superior de Tecnologia e Gestão, ARC4DigiT - Applied Research Center for Digital Transformation, Instituto Politécnico de Viana do Castelo, Viana do Castelo, Portugal

7 Dubai Healthcare City, PO Box 118855, Dubai, UAE 